\title{
The Deeper Life Bible Church and the Issues of Human Rights
}

\author{
S. A. Owoeye, Ph.D. \\ Department Of Religious Studies, Obafemi Awolowo University, Ile-Ife, Nigeria.
}

\begin{abstract}
Fundamental human rights are the inalienable rights of all members of human family. They are those rights which are characteristic of, or common to human beings. Such rights include; right to life, right to educate and be educated, right to own property, right to marry and be married, etcetera. These rights are guaranteed by the United Nations Organization (UNO) and constitutions of various countries of the world. These rights, as being practiced in the Deeper Life Bible Church, are the focus of this paper.
\end{abstract}

\section{Introduction}

The eighteenth and early nineteenth centuries are very important in the history of human rights. This is because it was during these periods that various attempts were made to prohibit many flagrant abuses of human rights. The movements against slave trade, killing of twins and ritual killing, which gathered pace in the eighteenth and nineteenth centuries, represent early attempts both at the international and local (national) planes to promote human rights. The efforts to outlaw the slave trade grew with the provision for human rights within the British Empire in 1807, and action against the slave trade was provided for in the treaty of Paris in $1814 .^{1}$

Also, at the treaty of Berlin in 1878, it was agreed that religious freedom would be allowed to those within the boundaries to the treaty. In 1840s, when the missionaries came for the second time for the planting of Christianity in Nigeria, ritual killing, the killing of twins and slave trafficking were stopped ${ }^{2}$. Since then, abuses of human rights have been reduced though not totally eliminated.

However, the missionaries tried to enforce freedom in all its ramifications in their churches but the freedom was not total. When other churches sprang up especially African Independent Churches (AIC), the missionaries were not happy that people were attending the new churches for divine healing instead of their own churches and hospitals. An example of this was when the Celestial Church of Christ was growing rapidly; there were reactions against the church. As Agbaje puts it;

As a result of the rapid growth of the Celestial Church and the popularity of Oshoffa, reactionaries and detractors set themselves to undermine the new religious movement and its leadership. ${ }^{3}$

Besides this observation, when the Colonial Administration and the Mission Churches found out that the Celestial Church was really a hard nut to crack, moves were initiated to restrain and control the prophet and the activities of the church. Agbaje explains further that:

A condition was given to the prophet that if he wanted recognition, he should register with the Council of Protestant churches in Dahomey (Republic of Benin). Tied to this was a clause which ordered the compulsory return of the deflected members to their parent churches... ${ }^{4}$

If the missionaries had encouraged the total operation of fundamental human rights, why should they be unhappy when people were exercising their freedom to join any church they wished? People should be free to

join any religious assembly and they should be free to leave the church if they wish. The trend was not totally different till the time when the Deeper Christian Life Ministry (D.C.L.M.) was established in 1973.

The Deeper Christian Life Ministry was established as an interdenominational ministry by Williams Kumuyi in $1973 .^{5}$ The ministry later started Sunday services with the maiden service on Sunday, November 7, 1982. The ministry then started an arm known as the Deeper Life Bible Church. Other arms of the ministry include the Deeper Life Students' Outreach (D.L.S.O.) which is meant for secondary school students and the Deeper Life Campus Fellowship (D.L.C.F.) which is for students in higher institutions, and so on and so forth. Church.

This paper, therefore, looks at the operation of fundamental human rights in the Deeper Life Bible

The church, from the time it was planted has been enjoying some freedoms. This, in modern parlance, is referred to as fundamental human rights. These rights cover many facets of life; from liberty to live, freedom of expression, freedom to marry and be married to, freedom to acquire various items of property, right to shelter, food and clothing. These rights are still in operation in the church today. The respect and primacy accorded human rights are because, in the words of the preamble to the two International Covenant of 1976, they "derived from the inherent dignity of the human person". ${ }^{6}$ The human being everywhere is endowed, whether by God or 
by nature, with innate spiritual attributes, not possessed by non-human beings - the faculty of rational thought, the faculty of inner spiritual feelings and emotions, and the faculty of judging right and wrong and of belief. The human soul is the divine nature of God implanted in the human being. These human rights have been given a global recognition. In 1993, the World Conference on Human Rights adopted the Vienna Declaration and Programme of Action which states, among other things that:

All human rights are universal, indivisible, interdependent and interrelated. All international community must treat human rights globally in a fair and equal manner, and on the same footing, and with the same emphasis. While the significance of national and regional peculiarities and various historical, cultural and religious backgrounds must be borne in mind, it is the duty... to promote and protect all human rights and fundamental freedom. ${ }^{7}$

How these rights are still being allowed in the church today especially in the Deeper Life Bible Church is important and worthy to be studied. A participant observation method which focused on the freedom of workers and members in the church vis-à-vis the teachings of the church and a much greater amount of observation focused on the discipline of workers and members are the instruments used in writing this paper.

\section{Human Rights as practiced in the Church}

The right to life is conferred on every individual, first by $\mathrm{God}^{8}$ as the creator. The same right was recognized by Jesus Christ and it was upheld by the early church. The need to protect life is taught by the Deeper Life Bible Church. The right to live or exist is also being protected by the International bodies and most countries of the world. This is because the life of every human being is sacrosanct and cannot be taken away or be disturbed anyhow. In order to ensure this, many provisions were put in place. Article 3 of the Universal Declaration of Human Rights provides that:

Everyone has the right to life, liberty and security of persons. ${ }^{9}$

The International Convention on Civil and Political Rights provides in its Article 6 paragraph 1 to the effect that:

Every human being has the inherent right to life. The right shall be protected by laws. No one shall be arbitrarily deprived of his life. ${ }^{10}$

The Nigeria's Constitution also provides as follows:

Every person has a right to life and no one shall be deprived intentionally of his life, save in execution of the sentence of a court in respect of a criminal offence of which he has been found guilty in Nigeria. ${ }^{11}$

Nigeria and other international organizations or bodies and churches have made ample provisions for the protection of life. One then would have thought that the Nigerian streets should be full of fulfilled people who enjoy an unassailable sense of security. But on a number of occasions, newspapers are filled with unpleasant news of assassination; of human corpses, sometimes found littering our busy highways, abandoned to decay. Other samples have been victims of frustrations, poverty, and hopelessness resulting from unrealizable objectives, inability to feed and provide shelter for them.

However, the Deeper Life Bible Church has tried to emphasize sanctity of life and other rights which are due to all and sundry. In the Church, people are made to study the text of the Bible to see its importance to the church, society and its applicability to any human society. Many passages are related to life and its preservation. People are acquainted with many topical issues in the Bible such as evil and how to avoid evil deeds which usually lead to unpleasant consequences and loss of lives. Pastor W.F. Kumuyi undertakes the teaching and interpretations of the Bible and members are free to apply the teachings to their lives. In this way, new types of selfhood are constituted through the activity of reading and studying of the scriptures. Thus the members redefine themselves in relation to the world. The interpretation of the Bible is the sole right of Pastor Kumuyi whom the church members believe cannot err and if he errs as a human being, the members are still ready to accept his interpretation.

Furthermore, the church has emphasized the significance of life and enjoined members to have deep respect for life whether of man or any living creature. This is because life belongs to God and it must not be cheapened or devalued in any way. In the teaching of the church, God wants His people to learn that every aspect of their lives, including what to eat or not to eat, must be subject to His will. ${ }^{12}$ In this regards, members, like Christians elsewhere, are to avoid eating of blood either as a delicacy on its own or along with the carcasses of any animal.

Although the preservation of life without the means of its sustenance and preservation is delicate, precarious, fragile and short, like the one described in Thomas Hobbes state of nature in his social contract theory where life is brutish and short, ${ }^{13}$ the Deeper Life makes provisions for further preservation of life through constant enlightenment. Just as the International Law has enlarged the scope of Human Rights to make life worth living for the global community, the church does not just protect and preserve the sanctity of life through 
her teachings, doctrines and sermons but provides for social and economic rights of members. Members are encouraged to choose any career of their choice. The church organizes various tutorials for students and graduates are encouraged to look for any work they can do with their hands and intelligence not necessarily in government establishments. However, idleness is discouraged based on biblical principles. ${ }^{14}$ This is because development does not come by itself, like manna from heaven, it is brought about by people applying all the hard work, self-reliance, initiative, creativity, enthusiasm and entrepreneurship of which they are capable if properly instructed. In this direction, many unemployed graduates of the church have established schools that are flourishing among which are Faith Standard Primary and Secondary School, Damico's Extramural, Primary and Jamb coaching classes, etcetera in Ile-Ife and other places

\section{Freedom to be educated and freedom to use medical facilities}

From the earliest days of the missionary activities in Nigeria, education and provision of health facilities had been placed within the reach of the common masses. This was because the two were regarded as essential and basic needs of the masses even though the two promoted the missionaries' evangelical work. The schools which were established and the kind of education which the missionaries gave were not to meet the social and material needs of their converts but to produce school masters who were to graduate to catechists, deacons, priests and interpreters but they gave the indigenes an ample opportunity to read and write ${ }^{15}$ The literacy which they offered gave Christians the power to enter into deep understanding of God's word and opportunity for personal evangelism which brought individual Christians into what the Nigerian charismatic religious leader W.F. Kumuyi now describes as a personal knowledge of Jesus Christ as their saviour and Lord. ${ }^{16}$ In 1859, the C.M.S. established C.M.S. Grammar School; the Methodist Mission established Methodist High School in 1877; American Baptist Mission established St. Gregory College and Baptist Academy. ${ }^{17}$ The Roman Catholic Church established Agricultural School of St. Joseph at Topo, Badagry in 1875. This latter school was reputed for instilling discipline into little children. In fact, many disobedient and recalcitrant ones were frightened and threatened to be sent there for reformation whenever they disobeyed.

Besides, the missionaries helped to cure ailments through Western drugs. To this effect, the C.M.S. established Iyi Enu Hospital near Onitsha in 1914; the Baptist established Hospital in Ogbomosho, Iwo and Eku.

The Methodist established the Wesley Guild Hospital in Ilesa. The Sacred Heart Hospital was established by the Society of African Missions in Abeokuta. In fact, the Roman Catholic Church established Hospital in almost all the dioceses and large parishes. For instance, St. Phenomena Hospital in Benin City, St. Camelius Hospitals in Uromi in Edo State, St. Andrew Hospitals in Onitsha, St. Nicholas Hospital in Lagos, Catholic Hospitals Oluyoro, Ibadan and Oshogbo. ${ }^{18}$

All these are to emphasize the fact that the historic churches offered and still offer the people the opportunity to be cured in the western way. In the same vein, the Deeper Life Bible Church allows freedom to patronize any of the Hospitals in their locations since the constitution allows all citizens the right to avail themselves of the available drugs in the hospitals for their health. Governments whether local, state or federal establish more hospitals in order to cope with people's health demand. Unlike the Apostolic Faith which does not allow her members to patronize hospitals or donate blood for others who may be in dire need of blood, the Deeper Life Bible Church does not disallow transfusion of blood. In fact, whenever sick members or any of the pregnant women are in need of blood, young healthy members (preferably workers) are informed and they voluntarily donate blood for them. The interest of the church is to ensure adequate security of human life at all times. The church does not however support the practice whereby a sick person would be taken to a herbalist (Babalawo) or diviner for healing. This practice is regarded as idolatry, that is, the practice of depending on or invoking another power besides God. This does not mean that some members would not be secretly attending herbal homes for healing. Also, it does not mean that some people are not cured through herbal medicine, but the practice is not approved by the church. Obviously, the ambivalence or hypocrisy is common in many churches today including the Deeper Life Bible Church when it comes to healing or seeking for issues through orthodox, divine and herbal methods.

Apart from the above, the Deeper Life encourages people to partake of divine healing which comes through prayer of faith to God. This is in addition to hospital facilities which people enjoy. The church, unlike a few others who would not want their members to study law, pharmacy, and medicine, does not restrict or limit people to certain careers. The church encourages people to read and reach the peak of their academic careers in any discipline. However, the church does not encourage people to go into politics. Sometimes, the church like other churches elsewhere, raises offering to assist indigent students in order to complete their studies in schools.

\section{Right to Fair Hearing}

The right to fair hearing is the right to listen to any offender before any verdict is pronounced. This right is recognized by God and it was applied to Adam and Eve in the Garden of Eden when they ate the forbidden fruit. ${ }^{19}$ De Smith confirms this when he writes: 
Even God himself did not pass sentences upon Adam before he was called upon to make his defense. God says "Adam where art thou?" Have thou eaten out of the tree whereof I commanded thee that thou should not eat?"20 The concept of fair hearing has been amplified by Denning M.R. to mean that:

If the right to be heard is to be a real right which is worth noting, it must carry with it a right in the accused man to know the case which he has been given and what statements have been made affecting him, and then he must be given a fair opportunity to correct or contact them. ${ }^{21}$

In agreement with the above, the Gospel according to St. John (John 7:51), has pointed out that the law would not judge a man or condemn him without hearing him. It states:

"Doth our law judge any man, before it hears him and knows what he doeth". 22

In the Deeper Life, offenders are allowed to defend themselves against any accusation. In the church, members are enjoined to avoid tale bearing and hatred as these are against good personal conduct but members are to report any erring members to their local pastors or coordinators who would then interview the erring members. If it is a matter of slight omission, upon admission of guilt, the person would be rebuked. But, if they are cases bothering on adultery, physical combat, stealing or embezzlement etc, the offenders would be invited upon availability of evidence to defend themselves before the local pastors. Nevertheless, if the cases appear intractable to the local pastors or coordinators, such cases would be referred to the region overseers or further to state overseers or finally to the General Superintendent (Pastor W.F. Kumuyi) for arbitration and final verdict.

Whatever happens, the aspect of fair hearing in respect of audi alteram partem which qualifies an accused to be heard before being judged must have been fulfilled. ${ }^{23}$ Also, where any minister of region or state overseer is caught in any sin or is a party to any dispute or has interest in any of the parties to a dispute, the case would be handled by the General Superintendent who would order a thorough investigation into the matter. Upon available evidence, Pastor W.F. Kumuyi, with or without a few ministers, would adjudicate and final verdict would be pronounced by the General Superintendent. Under no circumstances would any of the parties to any dispute be allowed to participate in the adjudication exercise in agreement with the second principle of fair hearing known as nemo judex in causa sua (nobody can be a judge in his own case). ${ }^{24}$

Other disputes or disagreements are resolved among members using biblical pattern of settling dispute in Matthew (18:xv). The offended tells the offender his fault. Upon admission of offence and apology, the disputes or disagreements automatically terminate. But, if the offender refuses to admit that he has offended his or her brother, the offended goes to him or her with another person. If he remains adamant and would not accept his fault, the offended is enjoined to report to the local pastor (church) who would invite him in order to settle the matter. If at last, the offender refuses to agree, the offended should forget about it and regards him as an infidel. ${ }^{25}$

However, litigation is not allowed and encouraged among members of the Deeper Life Bible Church. This is in compliance with Paul's instruction in the first Corinthians (I Corinthians VI). Members are to settle disputes among themselves. Members are advised to prefer to suffer for their brethren instead of going to court to commit illegality against God's instructions. Although in case of land issues, members are advised to contact all important people that are involved in the sale of the land before purchasing any piece of land. Where possible, lawyers should be contacted so as to purchase a valid parcel of land that would not end up in litigation with land vendors. In spite of all the precautions, the church has witnessed a few cases where some individuals have decided to encroach on the church land in different locations. Many individual members have witnessed encroachment on their lands, leading to communal arbitration. Although it is difficult to prevent any member who wishes to go to court for judicial arbitration but such is not encouraged. Similar things happened to the CMS in 1924 when the Roman Catholic Church encroached on their land at Ipetu-Jesa. ${ }^{26}$ Though, the Deeper Life does not encourage litigation, in some cases, litigation is inevitable.

\section{Right of Worship}

In Nigeria, each individual does, of course, possess the basic right to believe what he chooses, to worship whom he pleases and how he pleases, provided that he does not interfere with or encroaches on the right of others to worship whoever they want. The constitution of the Federal Republic of Nigeria guarantees freedom of worship. Worship has a central place in religious thought and practice. Religious rituals are structured around the worship of God, and central theological notions such as sin, atonement and salvation which involve implicit reference to worship. ${ }^{27}$ Worship involves affective and emotional attitude such as awe, an attitude that might be regarded as a certain type of fear. To worship something seems to involve judging that the object of worship is more powerful in some respect than oneself.

Since the constitution allows every citizen to worship that God in the way they understands, the Deeper Life teaches her members how to approach God's presence with reverence and honour for God. The need for reverence underpins a set of institutions which God gives to people in respect of their conduct before, during and after different services. Such instructions are echoed and re-echoed by the church to both members and visitors. It is a common practice for the Deeper Life members to invite different people for the church services. 
Nobody is discriminated against in terms of race, colour, age, sex when it comes to participation in worship on Sundays and other days of services. This freedom in the church enables people to worship God - all powerful objects of worship and the power that is beyond men!

Although according to Bayne (2006:300) that it is not obvious that the power in question need be a power over oneself, but it is a power that one lacks. ${ }^{28}$ Also internal to the attitude of worship is reverence - a form of humility and respect. Nigeria, being a multi tribal, ethnic and multi religious country, allows adherents of religious groups to practice their religions without using abusive or provocative words that may cause religious disharmony in the country. This is because many religious riots have been recorded in the past.

\section{Freedom to Marry and be Married}

The church regards marriage as a holy institution which was initiated by God. Marriage is seen as a holy union, a living symbol of Christ and his church, a precious relationship that needs tender self-sacrificing care because marriage is binding for life. Marriage is therefore a right of every Christian. But believers are not to go and be searching for wives or husbands; neither should any believer resort to the abominable, ungodly or unholy method of 'sampling' or 'picking and choosing ${ }^{29}{ }^{29}$ Conscious of this right to marry, the church highlights pre-requisites for such union. Prominent among which is salvation, the person must have been 'born again' and must have been divinely led to a particular sister, who must have been 'born again' as well. The church is aware of the fact that some may be in the church with the sole purpose of marriage and not for essential reason of being born again or the aim of worshipping God.

However, nationality, ethnic affiliation, education, colour or height is not a barrier. Once the marriage is contracted, it is "until death do us part". The wife is entitled to protection from indecent assault, dangers and illnesses ${ }^{30}$. The husband must provide for his wife while the wife is also to hold her husband in reverence. The husband and wife are to worship God together to raise godly children. But, at times, some workers of the church, because of their too much pre-occupation in church works, do not have time to take care of their children. Consequently, many children become heady, uncontrollable and ungodly. But if the child of any worker misbehaves or displays any trait of ungodliness in the public, immediately the parents are relieved of their posts in the church.

Although, the church does not discriminate on the ground of sex, nationality, colour, education etc, but the church does not join HIV positive individual with another who has not tested positive. This underscores the importance of blood test and HIV/AIDS test in the church before two people can be joined together in wedlock. Where would-be-husband and wife are AS, AS, they are advised not to marry to avoid children with sickle cell anemia in future. However, many have argued that the church that believes in the power of Holy Spirit and in divine healing should not have taken this posture, after all, there is nothing impossible for God as they claim. With fervent prayers and devotion to God, many believe that the condition of anybody can be changed for better. The church in this case may not want to take anything for granted as God is not under any law or compulsion to do anything. Even though, He has power to do all things, but at times, He may refuse to do some things and nobody can query Him. Besides, the couple may not be able to discipline themselves as to pray fervently enough to change their condition for better. However, Deeper Life members marry within the church, they do not marry from outside anyhow. This is why many people have alleged that members have not been given enough freedom to choose from wherever they want. Their fundamental right here is not full.

\section{Right of Children to Protection and Care}

According to the teaching of the Deeper Life Bible Church, children are entitled to be nurtured and trained to adulthood by their parents. In order to instill into them the fear and admonition of God, they are to be well grounded in Christian doctrines. Besides, they are to be sent to school for acquisition of skills in respect of their future professions. In addition, parents are to provide food, clothes and shelter for their children. They must encourage them by way of training them to be hard working.

Parents are however forbidden from abusing their children for whatever reason. They must not allow them to embark on any labour that may jeopardize their education or health. The church takes this stance because many people in other denominations abuse their children today because of money. Many poor parents allow their daughter to go abroad possibly for prostitution when they cannot take care of them. Child abuse has been the subject of legislation in many parts of the world (Microsoft Encarta Reference Library, 2004). ${ }^{31}$ In Great Britain, the first notable legislation against child abuse was enacted in $1878 .{ }^{32}$ In many parts of Nigeria, especially in the South-Western Nigeria, child abuse is the order of the day. Many children are used as cheap labour in many towns. This is probably because of the prevalence of poverty in the society. Many are forced by their parents, guardians or circumstances to seek employment in more rigorous, informal, menial but less rewarding enterprises. Many children of school age are seen carrying every form of ware on their heads for sale, instead of being in schools. Invariably, many children become victims of ritual killing, "hit-and-run" drivers and other crafty kidnappers. Many children who are wandering about are, at times, picked up by the 
roads' side and are displayed for the public to identify on the television screen by the Nigerian Television Authority (NTA). In most case, these are children of Christians from various denominations. Also, Osun State Broadcasting Corporation (OSBC) makes announcements concerning lost but found children on a regular basis. ${ }^{33}$ All these are discouraged by the Deeper Life Bible Church. Although this is not to say that all is well because some people are still careless with their children

\section{Reflections}

The Deeper Life Bible church allows her members to embark on various academic careers, but the church does not encourage them to be involved in politics even though like other citizens of Nigeria, they desire and pray that honest people be involved in Nigerian politics. This is because since independence in 1960, Nigeria has been bedeviled with massive corruption and gross financial mismanagement. But the questions which people often raise are: where would the honest people come from if the Deeper Life Bible church takes this stance and if other churches like them should instruct their members to avoid politics? If Christians opt out of political and social action, how can God relieve the oppressed? If Christians ignore politics, how can God be relevant in areas of injustice? If Christians turn blind eye to racial tensions and inequalities, which if in power, they can correct, how can we say that man - any and every man - is made in the image of God and what does it mean to proclaim that, in spite of man-made barriers, all are one in Christ Jesus? The church's arguments hinge on the fact that their members can backslide from God if they are exposed to the temptation of money in a society where there is greed for materialism. Members' rights to choose politics as career are already circumscribed by the church.

Although the church cannot be totally castigated for doing this because another dimension to Nigerian politics is involvement of politicians in occultic practices, acquisition of magical power for protection and mobilization of hoodlums or hooligans for political campaign and successes at polls, but everybody still think that Christian churches must produce better people for politics. In addition, politics in Nigeria involves the use of hooligans and assassins to eliminate rivals and political opponents. Money spent on mobilization of hooligans and elimination of political rivals through assassins are often obtained from public allocation when elected into offices. The risk of life that is often involved in participation in politics in Nigeria is one of the reasons why the Deeper Life Bible church does not allow her members to dabble into politics. Although the church has sufficient reasons to disallow their members from involvement in politics, yet the posture can make people look at the church as doing great disservice to the country.

The Deeper Life Bible church is somewhat strict in the area of marriage. The church allows members to marry within the church but it appears that they cannot marry from the mainline or 'Aladura' churches. This is as a result of the belief that most of the churches have deviated from the truth of the scriptures and many marriages there have failed. However, the only exception of course, is if the bride or the groom is a Christian in another gospel church. On that ground, the church can concede that such brother or sister be allowed to marry the bride or the groom. But, if the bride or the groom is not in any gospel church, the marriage would not be contracted. The church considers marriage with 'unbelievers' or people from outside the church especially those who are not born again as 'unequal yoke with unbelievers'. Where ladies outside the church are fanciful and loveable to members, they dare not propose to them for holy wedlock. If any careless proposal should be made by anybody in that direction, it would be turned down. How free are members then in choosing their life partners? The church always wants to play the role of a father who does not want any of his children to fail, especially in any marital issues. But are all the marriages so far contracted in the church since her inception successful? In 2005, the General Superintendent ordered the announcement of excommunication of a 'renowned' member who had left his wife and married another one and would not yield to all persuasions. However, the posture of the church would help their members to avoid bigamy and live disciplined lives. ${ }^{34}$

The church, just like the constitution of Nigeria or other nations, guarantees personal liberty of members. But, by qualifying the word liberty by the word 'personal', the import of the word liberty is narrowed down to the meaning given in English law to the expression 'liberty of the person' or personal freedom, freedom not to be forced to do things, freedom to choose and be chosen for any post. ${ }^{35}$ In the Deeper Life church, this liberty or freedom is restricted to some extent just as any country would not guarantee absolute freedom for her citizens. For instance, members are not allowed to have close intimacy with the opposite sex. This is to forestall immoral practices or indecent thoughts. Besides, workers are not allowed to travel or absent themselves from meetings without any prior permission from their district pastors or district coordinators. Workers must attend all workers' meetings on either weekends or any special days. Absence from workers' meetings without any substantial and convincing reasons would lead to discipline which could be suspension, withdrawal or total stoppage from working in the church. Workers must abide with all instructions from the church. This stance, according to the church, is to curb lawlessness among workers. But workers in the Deeper Life Bible Church cannot wear lace materials and 'Aso-Oke' ${ }^{36}$ clothes, neither can they buy or watch television even if they desire to do so. The leaders believe that in spite of the fact that television is educative because it can teach (through 
debates), illuminate and inspire people to do some good things, yet it can, as Tilly suggests, cause negative academic effects on the children who watch television more than ten hours a week and can debar children and adults from spending enough time with God in prayers. ${ }^{37}$ Besides, other evils like crimes and immoralities are conceived to be associated with the use of television. This is why workers are banned from using it. Surprisingly enough, last year, that is, October, 2009, the church decided to preach on the television (D.S.T.V) and yet, workers are not allowed to purchase it. The instructions are designed to keep their holy living, but then, their freedom has been encroached upon.

The church permits an individual to acquire his or her property but the church emphasizes moderation in all things. At times, the level of moderation appears ambiguous. This is because what constitutes moderation for ' $\mathrm{A}$ ' may not constitute moderation for ' $\mathrm{B}$ '. The levels of blessings from God are different. Aside, there are many activities in the Deeper Life Church to the extent that the freedom of many workers to address personal issues has been jeopardized. This is why some workers complain of not having enough time for their personal works and some absent themselves from workers' meeting at will in defiance of punitive measures that may accompany such absenteeism.

The practice of human rights in the Deeper Life Bible Church as being critiqued shows that there are still some impediments to the effective realization of full scale Human Rights in the church. In all, it appears that the optimism that human right practice will improve significantly in the church is obvious.

\section{Conclusion}

From what has been discussed so far, we have seen the fundamental human rights from religious perspective especially in the Deeper Life Bible Church. Since the doctrines in the Bible remain the bedrock of faith in the Deeper life, the church proclaims a radical doctrine of separation from worldliness and all sinful practices but with due regards to Fundamental Human Rights which the bible and the constitution of the land guarantee. The aim of the church is to teach the common Christian ideals to be attained by all people and all nations, in order that by instruction and education, people might have respect for these rights and freedom. Or of what use will right to family be to broken families whose children are separated from them if they are not taught how to keep their families together with the fear of God.

The rights, from what we can see, are not artificial or mechanically inserted by human beings. The violation of human rights would invite punishment from government (men) while their infringement would equally invoke divine wrath which may be devastating and total.

\section{References}

[1]. T.F. Yerima "Internationalisation of Human Rights: A Critical Appraisal and comparison of the Trilogy of Documents in the U.N. system" in Ikeja Bar Review, vol 1 parts I and II, Sept., 2006 - Mar. 2007 p.27

[2]. E.A. Ayandele: The Missionary Impart on Modern Nigeria 1842 - 1914 London: Longman 1966 p.8

[3]. A.A. Agbaje "Rev. S. B. J. Oshoffa 1909 - 1985" in J.A. Omoyajowo (ed) Makers of the Church in Nigeria (Lagos: C.S.S., 1995), pp.170 - 193 Ibid p.186.

[4]. M.A.Ojo: "Deeper Christain Life Ministry: A case study of the Charismatic Movement in Western Nigeria" in Journal of Religion in Africa vol. xviii, 2(1988)

[5]. Okpara Okpara: Human rights: Law and Practice in Nigeria Enugun: Chenglo, 2005 p.36

[6]. Ben Nwabaeze: Constitutional Democracy in Africa vol.2 Ibadan: Spectrum, 2003 p.4

[7]. Exodus 20:13 (King James Version), p.1611.

[8]. A.L. Akintola "Making the Life more meaningful under the Nigerian Constitution" in a Journal Ife Juris, vol.1, Part 2, 2004, p.359

[9]. International Convention on Civil and Political Rights Article 6. Section 33 (1) 1999 Constitution of the Federal Republic of Nigeria.

[10]. Laws about special sacrifices in Deeper Life's Search the Scripture, vol. 25, p.18. A.L. Akintola, Ibid, p. 360.

[11]. Deeper Life: Building the Body, vol.8, (Lagos: Deeper Life Press), pp.27-30.

[12]. E.A. Ayandele, The Missionary Impact on Modern Nigeria 1842-1914,

[13]. Ibid p. 286.

[14]. Stephanie Newell, "Devotion and Domesticity: The Reconfiguration of Gender in Popular Christian Pamphlets from Ghana and Nigeria" in Journal of Religion in Africa, vol. 35.3 (2005), p.304)

[15]. E.A. Ayandele: The Missionary Impact on Modern Nigeria 1842-1914,

[16]. Ibid, p. 289.

[17]. Don Akhilomen: “Addressing Child Abuse in Southern Nigeria; The Role of the Church" in Studies in World Christianity. The Edinburgh Review of Theology and Religion, vol. 12, Part 3, 2006, p.244.

[18]. Genesis 3, 11. 12 (The Holy Bible R.S.V.)

[19]. S.A. De Smith: Judicial Review of Administrative Action ( $3^{\text {rd }}$ Ed.), 1973. S.M. Evans Steven. See also John Chapter 7 verse 51 where it is also pointed out that the law would not judge a man or condemn him without hearing him. It states "Doth our law judge any man, before it hears him and know what he doeth", John 7:51; Gen. 4:9-12.

[20]. Hakeem Ijaiya: "The Rule of Law, Democracy and Basic Principles of Human Rights in Nigeria" in Ife Juris, vol. 1, part 2, 2004, pp.371. Also see C.A. Oputa "Human Rights in the Political and Legal Culture of Nigeria", Idigbe Memorial Lecture 1986, p.99.

[21]. John VII: 51 (Holy Bible, R.S.V.).

[22]. B.O. Iluyomade and B.U. Eka: Cases and Materials on Administrative Law in Nigeria (Ife: University of Ife Press 1980, 1984), p.131. See also J.F. Garner Administrative Law, $6^{\text {th }}$ edition (London: Butterworths, 1985), pp.156-158. Ibid.

[23]. Matthew 18: 15-17 (The Holy Bible, R.S.V).

[24]. S.A. Owoeye "A History of Roman Catholic Mission in Ijesaland", being an unpublished M.A. thesis submitted to the Department 
of Religious Studies of University of Ife, now Obafemi Awolowo University, Ile-Ife in 1985, p.65.

[25]. R. Otto: The Idea of the Holy (Oxford: Oxford University Press, 1958 and edition). Also N. Smart, The Concept of Worship (London: Macmillan, 1972). E. Underhill Worship (New York: Harper and Row, 1936); and Mark Wynn, God and Goodness (London: Routledge, 1999) especially chapter 6.

[26]. T. Bayne "The Ground of Worship" in Religious Studies: An International Journal for the Philosophy of Religion, vol. 42 No.3, Sept. 2006, p.300.

[27]. The Deeper Life Bible Church Doctrine on Marriage - Doctrine No. 14.

[28]. Ibid.

[29]. Microsoft Encarta Reference Library 2004 S.V. 'Child Abuse'; 'Child Labour' and 'Slessor Mary' Don Akhilomen, Ibid, p. 238.

[30]. The announcement about lost but found children and children who were found aimlessly wandering about was made by the Orisun F.M., an arm of the Osun State Broadcasting Corporation (OSBC) at Ile-Ife, Osun state, Nigeria, on Monday, October 13, 2008.

[31]. Announcement of excommunication of a brother who had abandoned his wife and had refused to yield to all persuasions was made by the Region Overseer (Pastor Festus Adedokun) at the 2005 Retreat in Moro, Ile-Ife. The excommunication was ordered by the General Superintendent, Pastor W.F. Kumuyi. The announcement was made simultaneously in all retreat centres in Nigeria.

[32]. "Concept of Human Rights: Its values and Importance" in Nwabueze Ben: Constitutional Democracy in Africa vol.2 Ibadan: Spectrum, 2003 p.19.

[33]. Aso Oke is any cloth made of expensive woven material. Tilley E.: Mass Media Module: Radio Television Film London: Media heritage, 2007 p.53. 